\title{
THERMAL ANALYSIS OF SOLAR PV-T WALL
}

\section{Y. SRINIVASA REDDY ${ }^{1}$, V. RAJA KIRAN KUMAR ${ }^{2} \&$ T. RAVIKUMAR REDDY ${ }^{1}$}

${ }^{I}$ Assistant Professor, Department of Mechanical Engineering, CMR Engineering College, Hyderabad, India

${ }^{2}$ Associate Professor, Department of Mechanical Engineering, CMR Engineering College, Hyderabad, India

\begin{abstract}
This paper represents the requirements imposed in recent years on buildings and their elements have been changing rapidly. Due to increased thermal resistance of the external building shell and significant reduction of the ventilation losses, the relations between the major factors of energy balance of the modern buildings are now completely different than they were before. A low energy technique for heat removal from the interior of a building under summer conditions is the employ of natural ventilation. Solar PV wall if placed over a conventional wall forming an air gap will produce electricity and also tap thermal energy by heating the atmospheric air by convection. Thereby the thermal energy on the surface of PV cells is removed by the air flow between the glass panel and wall, so that the temperature of PV cells decreases leading to higher electrical efficiency. Research is towards the analysis of such systems so as to deliver higher energy savings and to improve the cost effectiveness. Therefore the aim of this project is to do the thermal analysis of solar wall.
\end{abstract}

KEYWORDS: Vertical Solar Wall, Thermal Network \& Energy Savings

Received: Oct 19, 2018; Accepted: Nov 09, 2018; Published: Dec 20, 2018; Paper Id.: IJMPERDDEC201890

\section{INTRODUCTION}

Energy consumption in the building sector is an important factor which contributes to the increase in the total energy utilization. The utilization of solar energy has traditionally been divided into two fields on a single device, namely Solar Thermal Energy and Photovoltaic Energy. Photovoltaic, as the name itself says, is the conversion of solar energy into electricity by the utilization of silicon based solar cells. Solar Thermal Energy, on the other hand, is concerned with the utilization of solar radiation to provide useful heating. Akbari and Borgers [1] and Fedorov and Viskanta [2] performed a theoretical analysis of the natural convection laminar flow between two parallel plates and obtained velocity and temperature fields.

Normally, solar wall consists of a sun-facing glass wall separated from the outdoor wall forming an air space. Atmospheric air will be heated by utilizing the solar energy which is absorbed by the glass wall. The heated air is supplied for low thermal applications such as drying applications. Photovoltaic cells are typically composed of a P-type and N-type semiconductor. The semiconductors can be made of different materials such as mono or polycrystalline silicon, amorphous silicon, and cadmium sulphide or cadmium telluride. The P-type semiconductor has available electron-holes and the N-type semiconductor has free electrons. Therefore, when the two semiconductors are placed back-to-back, a potential difference is created in a region called the P-N junction. When intense light or solar radiation hits a PV cell, the photons with enough high energy can displace electrons, creating hole-electron pairs. For a Non- P silicon cell, these holes tends to collect on the back contact electrode while the free electrons move to the front contact electrode. 
When a load is connected to the front and back electrodes, electrons use the newly created path to return to the P-type contact grid, creating a current. Photovoltaic cells are known to convert only a small part of the solar energy they absorb into electricity. In fact, their efficiency is in the range of only 6-15\%, depending on the type of cells. The main reason for this poor efficiency is that only photons with a certain amount of energy are able to create holeelectron pairs. The photons with not enough energy or the ones that are left when the maximum amount of electron-hole pairs are created cannot produce electricity. Instead, their energy is converted to heat and contributes to raising the cell temperature. This heating up is undesirable for PV cells, because it decreases their electrical conversion efficiency. Thus the main objective of our project is to do the thermal analysis and energy modelling of a Solar -PV glass wall.

\section{SYSTEM CONSIDERED}

The system considered here is a south facing conventional wall separated by a solar -PV glass wall to form an air gap between them. Figure 1 shows the schematic view of the Solar PV wall placed in front of a conventional wall of a room. The photovoltaic pane absorbs the solar light intensity falling over it and converts into electricity. The increase in the temperature of the solar PV is prevented, resulting in an increase of the efficiency of the solar PV when compared with the conventional PV system. This is done by heating the atmospheric air through natural convection between the air gap formed between the Solar PV pane and the conventional wall.

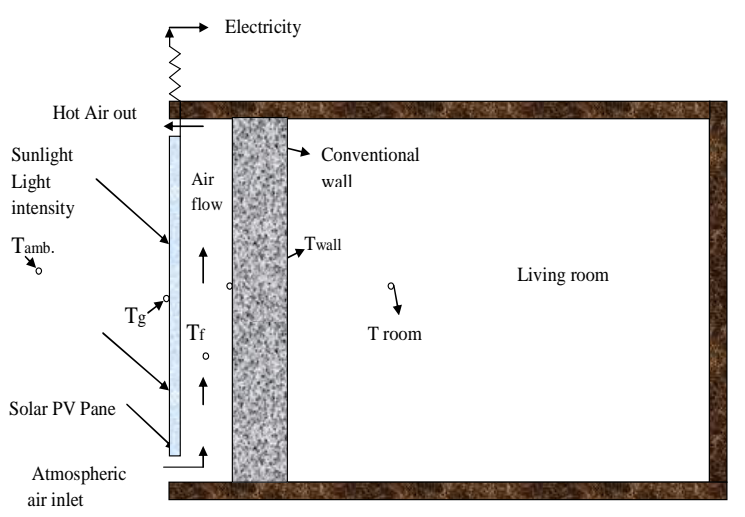

Figure 1: Solar Photovoltaic Pane Wall over a Room

The heated air is used for low thermal applications like drying applications and room heating during winter conditions. Also, the temperature of the room will be lower since the heat transfer to the room through the wall will be less when compared to a conventional room with ordinary walls. For commercial buildings to avoid flow blockage effects, the width of the channel should be more than $4.7 \mathrm{~cm}$ according to Anderson[2].

The air gap between PV and convectional wall can be from a minimum of $10 \mathrm{~cm}$ and maximum of $20 \mathrm{~cm}$. Photovoltaic solar wall thickness will be $3 \mathrm{~mm}$ whereas the thickness of convectional wall is $20 \mathrm{~cm}$ to $40 \mathrm{~cm}$. The wall is typically located on the south face of a building to maximize its solar exposure. One or more layers of glazing on the exterior and an optional selective surface turn the wall into a one-way heat valve and generating power using PV pane. Generally, materials used for photovoltaic panes are Mono crystalline Silicon which has an efficiency of 16-18\%, Polycrystalline Silicon which has as efficiency of 15-17\%, Amorphous Silicon which has an efficiency of 6-8\% and Cadmium Telluride which has an efficiency of $9-11 \%$. 


\section{THERMAL NETWORK DIAGRAM}

Thermal Network diagram is formed by considering four nodal points: $T_{\text {ambient }}, T_{p v}, T_{\text {room }}, T_{f}$ as shown in Figure 1 . This solar wall has been studied within the theoretical framework of Zalewski’s[16].

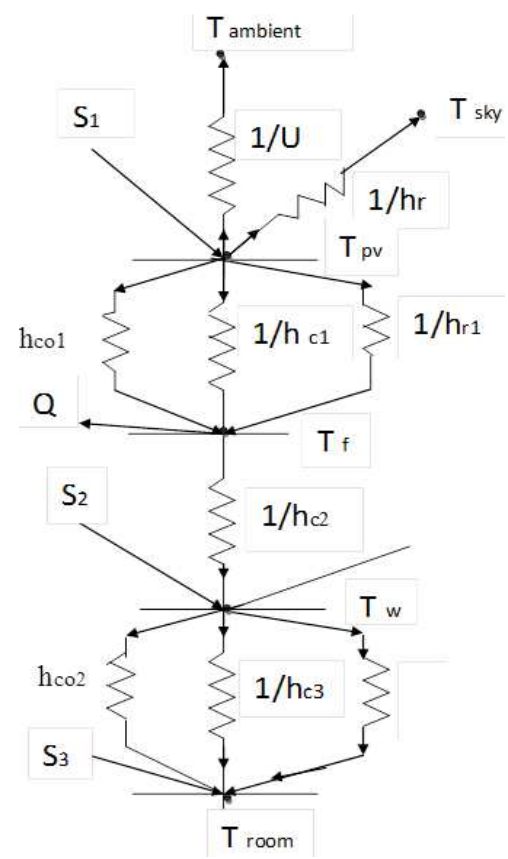

Figure 2: Network Diagram

\subsection{Energy Balance of PV Glass Panel}

The solar PV cells laminated on back of glass panel are very thin, the adherence between the glass and the PV cells is very tight and the heat conduction is good. However, because of the higher absorptiveness of PV cells compared to glass, the temperatures of the elements with the solar PV cells are not uniform. Hence, the temperature distribution of solar PV glass panel is to be considered.

For simplifying the calculations, it is assumed that the temperature of every solar PV cell is uniform and base centre grids are plotted along the boundary of every PV cell. The solar PV cell is so thin that its heat capacity can be neglected. Considering the heat capacity of the PV glass panel and the solar radiation, the energy balance equations of the solar PV glass panel are established according to figure 2 (thermal network diagram).

Node 1: For PV pane

$$
\mathrm{S}_{1}=h_{c o 1}\left(\mathrm{~T}_{\mathrm{pv}}-\mathrm{T}_{\mathrm{f}}\right)+\mathrm{h}_{\mathrm{c} 1}\left(\mathrm{~T}_{\mathrm{pv}}-\mathrm{T}_{\mathrm{f}}\right)+\mathrm{h}_{\mathrm{r} 1}\left(\mathrm{~T}_{\mathrm{pv}}-\mathrm{T}_{\mathrm{f}}\right)+\mathrm{U}\left(\mathrm{T}_{\mathrm{pv}}-\mathrm{T}_{\mathrm{a}}\right)+\mathrm{h}_{\mathrm{r}}\left(\mathrm{T}_{\mathrm{pv}}-\mathrm{T}_{\mathrm{sky}}\right)-\mathrm{E}
$$

Node 2: For air flow

$$
\mathrm{Q}=\mathrm{h}_{\mathrm{co} 1}\left(\mathrm{~T}_{\mathrm{pv}}-\mathrm{T}_{\mathrm{f}}\right)+\mathrm{h}_{\mathrm{c} 1}\left(\mathrm{~T}_{\mathrm{pv}}-\mathrm{T}_{\mathrm{f}}\right)+h_{r}\left(\mathrm{~T}_{\mathrm{pv}}-\mathrm{T}_{\mathrm{f}}\right)-\mathrm{h}_{\mathrm{c} 2}\left(\mathrm{~T}_{\mathrm{f}}-\mathrm{T}_{\mathrm{w}}\right)
$$

Node 3: For wall

$$
\begin{aligned}
& \mathrm{S}_{2}=\mathrm{h}_{\mathrm{co} 2}\left(\mathrm{~T}_{\mathrm{w}}-\mathrm{T}_{\mathrm{r}}\right)+\mathrm{h}_{\mathrm{r} 2}\left(\mathrm{~T}_{\mathrm{w}}-\mathrm{T}_{\mathrm{r}}\right)-\mathrm{h}_{\mathrm{c} 2}\left(\mathrm{~T}_{\mathrm{f}}-\mathrm{T}_{\mathrm{w}}\right)+\mathrm{h}_{\mathrm{c} 3}\left(\mathrm{~T}_{\mathrm{w}}-\mathrm{T}_{\mathrm{r}}\right) \\
& \mathrm{s}_{2}=\mathrm{s}_{1} *(\tau \alpha)
\end{aligned}
$$




\section{CALCULATIONS OF HEAT TRANSFER COEFFICIENTS}

In solar walls the heat transfer and the fluid flow are closely coupled phenomena. Calculations of wall surface temperatures, convective heat transfer coefficients and air velocity need to be performed at the same time in an integrated way. An analysis of the heat transfer and the air flow phenomena inside the air gap involves a number of correlations that can be chosen for the convection coefficient of the wall.

\subsection{Convective Heat Transfer Coefficient}

The convective heat transfer coefficient due to wind on the outside surface of the PV glass panel is given according toMc Adams [8] as

$\mathrm{h}_{\mathrm{a}}=5.7+3.8 \mathrm{v}$

The convective heat transfer coefficient is calculated using the Nusselt number $(\mathrm{Nu})$ from the relation:

$\mathrm{h}_{\mathrm{conv}}=\frac{\mathrm{Nu} * \mathrm{k}}{\mathrm{L}}$

where, Nu depends on the Rayleigh number (Ra) \& Pr and tl number (Pr) the latter being dependent on the type of fluid.

$\mathrm{Ra}=\mathrm{Gr} * \mathrm{Pr}$

Grash of Number, $\mathrm{Gr}=\beta \mathrm{g}^{2} \mathrm{H}^{3}\left(\mathrm{~T}_{\mathrm{pv}}-\mathrm{T}_{\mathrm{f}}\right)$

If $\mathrm{Ra}<10^{9}$ the flow is laminar \& $\mathrm{Nu}$ is calculated according to correlation of Churchill and Chu [18] as:

$\mathrm{Nu}=0.68+\left\{\frac{\left(0.67\left((\mathrm{Ra})^{\frac{1}{4}}\right)\right)}{\left[1+(0.492 / \mathrm{Pr})^{\frac{9}{16}}\right]^{\frac{4}{9}}}\right\}$

If $\mathrm{Ra}>10^{9}$ the flow is turbulent and Nusselt number is calculated as :

$\mathrm{Nu}=\left\{0.825+\left(\frac{\left[0.387 \times \mathrm{Ra}^{\frac{1}{6}}\right]}{\left[1+(0.492 / \mathrm{Pr})^{\frac{9}{16}}\right]^{\frac{8}{27}}}\right)\right\}^{2}$

\subsection{Radiation Heat Transfer Coefficient}

The radiation heat transfer coefficient on outside surface relative to inner surface can be written according to Jibao Shen [12]

$$
\mathrm{h}_{\mathrm{r}}=\left\{\frac{\left(\sigma\left(\mathrm{T}_{\mathrm{pv}}{ }^{2}+\mathrm{T}_{\mathrm{a}}^{2}\right)\left(\mathrm{T}_{\mathrm{pv}}+\mathrm{T}_{\mathrm{a}}\right)\right)}{\left(\left(\frac{1}{\varepsilon_{\mathrm{pv}}}\right)+\left(\frac{1}{\varepsilon_{\mathrm{a}}}\right)-1\right)}\right\}
$$

\subsection{Top Loss Coefficient}

The overall top loss coefficient is obtained over the outer surface of the photovoltaic panel surface is written according to Duffie and Beckman [7]. 
$U=\left\{\left(\frac{\mathrm{N}}{\left[\left(\frac{\mathrm{C}}{\mathrm{T}_{\mathrm{pv}}}\right)\left[\frac{\mathrm{T}_{\mathrm{pv}}-\mathrm{T}_{\mathrm{a}}}{\mathrm{N}+\mathrm{f}}\right]^{\mathrm{e}}\right]}\right)+\left(\frac{1}{\mathrm{~h}_{\mathrm{a}}}\right)\right\}^{-1}+\left\{\frac{\left(\sigma\left(\mathrm{T}_{\mathrm{pv}}+\mathrm{T}_{\mathrm{a}}\right)\left(\mathrm{T}_{\mathrm{pv}}{ }^{2}+\mathrm{T}_{\mathrm{a}}{ }^{2}\right)\right)}{\left[\left(\varepsilon_{\mathrm{pv}}+.00591 \mathrm{Nh}_{\mathrm{a}}\right)^{-1}+\left(\frac{\left[2 \mathrm{~N}+\mathrm{f}-1+0.13 \varepsilon_{\mathrm{pv}}\right]}{\varepsilon_{\mathrm{a}}}\right)-\mathrm{N}\right]}\right\}$

Where, $\mathrm{C}=520 *\left(1-0.000051 * \beta^{2}\right)$

$\mathrm{f}=\left[\left(1+0.089 \mathrm{~h}_{\mathrm{a}}-0.1166 \mathrm{~h}_{\mathrm{a}} \varepsilon_{\mathrm{p}}\right) *(1+0.07866 \mathrm{~N})\right]$

$\mathrm{e}=\left\{0.43 *\left(1-\left(100 / \mathrm{T}_{\mathrm{p}}\right)\right\}\right.$

\subsection{Electric Power}

Electric power rate $\left(\mathrm{W} / \mathrm{m}^{2}\right)$ generated by PV cells can be calculated according to Zondag [22] as

$\mathrm{E}=\mathrm{G} * \eta\left[1-0.0045\left(\mathrm{~T}_{\mathrm{pv}}-25\right)\right]$

Where, $\eta$ is the electrical efficiency under standard conditions $\left(850 \mathrm{~W} / \mathrm{m}^{2}, 28{ }^{\circ} \mathrm{C}\right)$ and $\mathrm{G}$ is the Solar Radiation

The temperature of photovoltaic cell is calculated using the equation from Zondag [22]as

$$
\mathrm{T}_{\mathrm{pv}}=30+0.0175[\mathrm{G}-200]+1.14\left[\mathrm{~T}_{\mathrm{a}}-25\right]
$$

\section{RESULTS AND DISCUSSIONS}

Figure 3 represents the variation of PV cell fluid outlet temperature with ambient temperature. With an increase in ambient temperature, then there will be an increase in the photovoltaic pane temperature and air flow temperature between the conventional wall and photovoltaic panel. To reduce the air flow temperature and to produce constant electricity from pane, the air has to be allowed to flow under the PV pane.

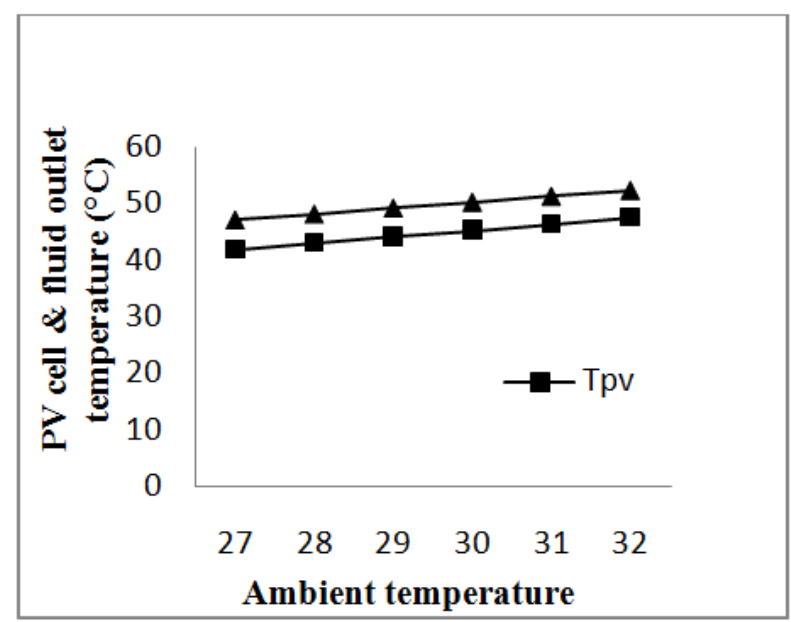

Figure 3: Ambient Temperature Vs PV cell \& Fluid Outlet Temperature

Figure 4 represents the variation of PV cell fluid outlet temperature with ambient temperature. With an increase in solar radiation and air temperature at the bottom of photovoltaic pane then there will be increase of thermal efficiency for low thermal applications and decrease in the efficiency of electricity. 


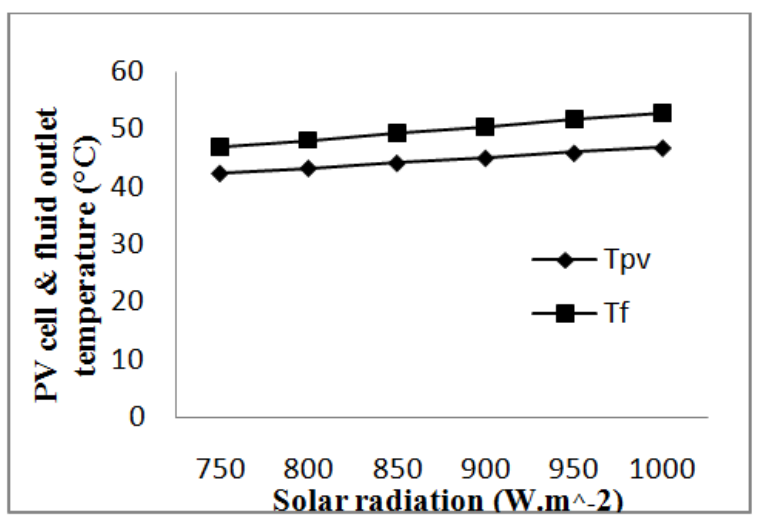

Figure 4: Solar Radiation Vs PV Cell \& Fluid Outlet Temperature

Figure 5 represents the variation of Heat transfer with mass flow rate over a photovoltaic pane. It can be observed that with an increase in mass flow of air at the bottom of the solar PV pane, the heat transfer increases.

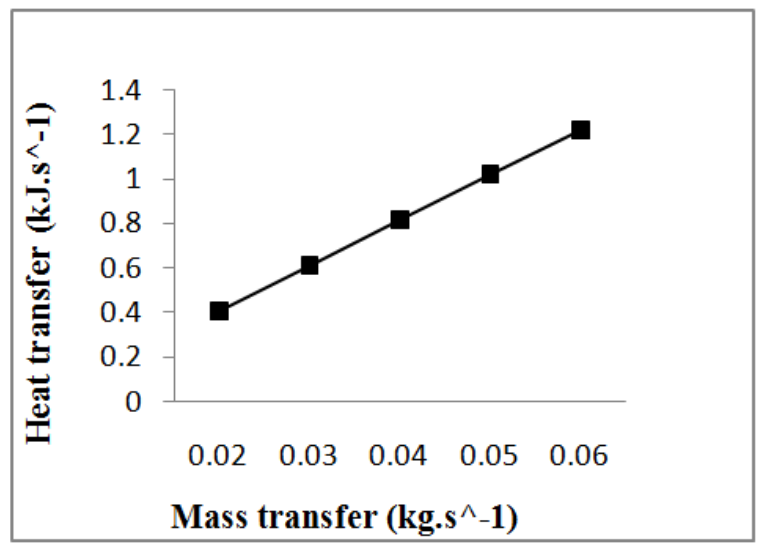

Figure 5: Heat Transfer (Q) Vs Mass Flow Rate

Figure 6 represents the variation of Thermal and Electrical efficiency with solar radiation. It can be observed that with a small increase in solar radiation, the efficiencies have almost remained constant while the thermal efficiency is greater than the electrical efficiency.

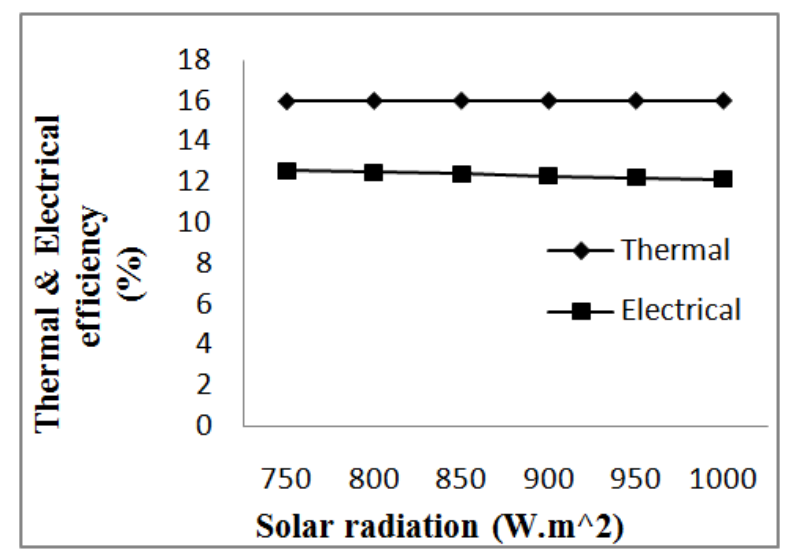

Figure 6: Solar Radiation Vs Thermal \& Electrical Efficiency

Figure 7 represents the variation of Thermal and Electrical efficiency with ambient temperature. It can be observed that with a little increase in ambient temperature, the efficiencies have almost remained constant while the 
thermal efficiency is greater than the electrical efficiency.

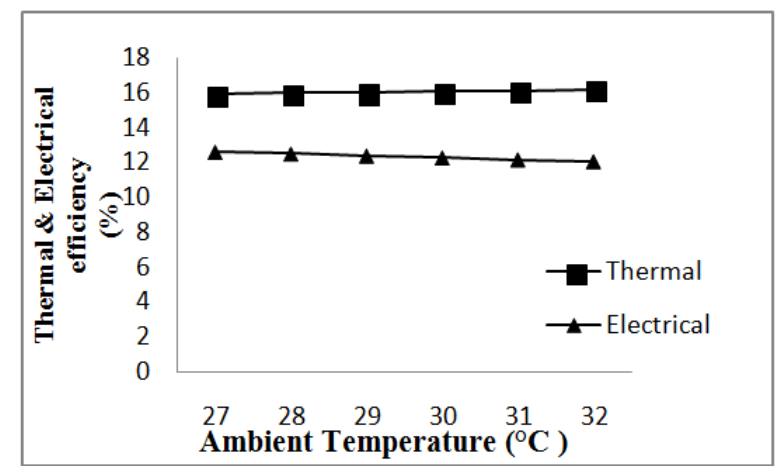

Figure 7: Ambient Temperature Vs Thermal \& Electrical Efficiency

According to ASHRAE 90.1 standard for continuous maintenance by the standing standard project committee (SSPC), a comparison between base case and PV wall has been made for electrical energy consumption and $\mathrm{Co}_{2}$ emission using Hourly Analysis Program 4.5 software. The observations made are shown in the table in Table 1.

Table 1: Hourly Analysis Program

\begin{tabular}{|l|c|c|}
\hline \multicolumn{1}{|c|}{ Details } & Base Case & PV Solar Wall \\
\hline Total area $\left(\mathrm{m}^{2}\right)$ & 2070 & 2070 \\
\hline Vertical wall area $\left(\mathrm{m}^{2}\right)$ & 165 & 165 \\
\hline Panel Area $\left(\mathrm{m}^{2}\right)$ & & 81 \\
\hline Electrical energy consumption $(\mathrm{KWh})$ & $4,06,932$ & $4,05,638$ \\
\hline CO2 Equivalent $(\mathrm{kg})$ & $2,86,789$ & $2,87,126$ \\
\hline
\end{tabular}

\section{COST ANALYSIS}

\subsection{Calculation Procedure}

Calculations for the area of solar PV wall which is been considered for the commercial office building is estimated by taking standard formulas from the literatures.

Area of the room considered $=99 \mathrm{~m}^{2}$

Area of panel $=1250 * 640 * 32.5 \mathrm{~mm}=0.8 \mathrm{~m}^{2}$

Maximum power of panel $=90 \mathrm{~W}$

Number of panels required $=123$ panels

Efficiency of each panel, $=0.12$

By considering the efficiency of panel $=0.12 * 8 * 90=86.4 \mathrm{Watt} / \mathrm{hr}$

Total number of panels generates the electricity, $=10.62 \mathrm{~kW} / \mathrm{hr}$

Cost of the single panel, $=$ Rs. $5000 /-$

Total cost of the panels $=$ Rs.6,15,000/-

With other investment costs total, $P_{i}$

$=$ Rs. $7,63,000 /-$ 
Operational and maintenance cost per year, $\mathrm{R}_{\mathrm{m}}$

$=$ Rs.40,000/-

Replacement cost in every five years, $R_{p}$

$=$ Rs. $1,20,000 /-$

Number of year, $n=10$ years

- $\quad$ Net Present Value

$$
\mathrm{P}_{\mathrm{NPV}}=\mathrm{P}_{\mathrm{i}}+\mathrm{R}_{\mathrm{m}} *\left(\frac{(1+\mathrm{i})^{\mathrm{n}}-1}{\mathrm{i} *(\mathrm{i}+1)^{\mathrm{n}}}\right)+\mathrm{R}_{\mathrm{p}} *\left(\frac{1}{(1+\mathrm{i})^{\mathrm{n}}}\right)-\mathrm{S} *\left(\frac{1}{(1+\mathrm{i})^{\mathrm{n}}}\right)
$$

$=$ Rs.11,16,751.93/-

\section{- Cash Flow}

$\mathrm{CF}=($ Daily hours used $* 365$ days/year $) * \mathrm{KW} *$ Electricity cost per unit $=$ Rs. $1,78,309.8 /-$

\section{- Payback Period}

Payback period, $\mathrm{n}_{\mathrm{p}}=\left[\ln \left(\frac{\mathrm{CF}}{\mathrm{CF}-\left(\mathrm{i} * \mathrm{P}_{\mathrm{NPV}}\right)}\right)\right] / \ln (1+\mathrm{i})$

$=7.713$ years.

From the above estimated cost of the initial investment and energy savings from the electricity billing amount, then the initial amount is recovered in the form of electricity saving from photovoltaic solar panels installation is 7.7 years for payback period from the investment.

\section{CONCLUSIONS}

It is concluded that the electrical efficiency of the solar PV wall modelled proves to be an energy conservatory device. The temperature of the room is $2^{0} \mathrm{C}$ lesser than the conventional case which means the electrical energy spent to lower this temperature difference is saved also the electrical energy generated from the solar PV wall is used to power the building. The cumulative effect of the electrical energy saving will turn the convectional building into a Net Zero Energy Building in the future.

\section{FUTURE ENHANCEMENT}

It is concluded that the electrical efficiency of the solar PV wall modelled proves to be an energy conservatory device. The temperature of the room is lower than the conventional case which means the electrical energy spent to lower this temperature difference is saved also the electrical energy generated from the solar PV wall is used to power the building. The cumulative effect of the electrical energy saving will turn the convectional building into a Net Zero Energy Building in the future.

Future Enhancement can be Thermal analysis using energy plus the software Nano material is used to reduce the cost of photovoltaic panels 


\section{REFERENCES}

1. H. Akbari and T. R. Borgers, "Free convective laminar flow within the Trombe wall channel," Solar Energy, vol. 22, no. 2, pp. 165-174, 1979.

2. G. Fedorov and R. Viskanta, Turbulent natural convection heat transfer in an asymmetrically heated, vertical parallel plate channel, International Journal of Heat and Mass Transfer, vol. 40, no. 16, pp. 3849-3860,1997.

3. Anderson. R. and F. Kreith, "Natural convection in active and passive solar thermal systems," Advances in Heat Transfer, vol.18, pp. 1-86, 1987.

4. Armstrong S., Hurley W. G. (2010). A Thermal Model for photovoltaic panels under varying atmospheric conditions. Applied Thermal Engineering 30, 1488-Ireland.

5. Bin J., Jie J. and Hua Y. (2008). The influence of PV coverage ratio on thermal and electrical performance of photovoltaic Trombe wall. Renewable Energy, China.

6. Dimassi N. and Dehmani L. (2012). Natural convection of a Solar Wall in a Test Room under Tunisian Climate. International Scholarly Research Network Renewable Energy vol., Art. ID 573176, doi: 10.5402/573176, Tunisia.

7. KB, S. S., \& DV, S. (2016). Thermal Analysis of Advanced IC Engine Cylinder.

8. Duffie JA, Beckman WA. Solar engineering of thermal processes. $2^{\text {nd }}$ ed. New York: Wiley; 1991.

9. Guohui G. (1998). Parametric study of Trombe wall for passive cooling of buildings. Journal of Energy and Building 27 3743, University of Nottingham, UK.

10. Mc Adams. W. H., Heat Transmission, 3rd ed., McGraw-Hill, New York, 1954.

11. Hirunlabh J., Kongduang W., Namprakai P. and Khedari J. (1999). Study of a natural ventilation of houses by a metallic solar wall under tropical climate. Renewable Energy 18 109-119, Bangkok.

12. Jie J., Hua Y., Gang P. and Jianping L. (2007). Study of PV-Trombe wall installed in a fenestrated room with heat storage. Applied Thermal Engineering 27 1507-1515, China.

13. Jibao Shen, Stephane L., Zalewski L., Dezhong H. (2007). Numerical Study on Thermal Behaviour of Classical or Composite Trombe Solar walls. Energy and Buildings, 39 962-974, China.

14. Jie J., Hua Y., Wei H., Gang P., Jianping L. and Bin J. (2007). Modelling of a novel Trombe wall with PV cells. Building and Environment 42 1544-1552, China.

15. Kalogirou S. A and Tripanagnostopoulos. Y. (2007). Industrial Application of PV/T solar energy systems. Applied Thermal Engineering, Vol. 27 pp.1259-1270.

16. Li Y., Duanmu X., Sun Y., Li J. and Jia H. (2007). Study on the air movement character in solar wall system, Building Simulation. Beijing University of Technology, Beijing.

17. Mahrous, A. (2013). Thermal performance of PCM based heat sinks. Int J Mech E

18. L. Zalewski, Etude thermique experimental et simulation numerique d'un mursolaire composite -Optimisation des performances energy techniques, These de doctorate (PhD Thesis), University dArtois, Bethune, France, 1996.

19. Stanko S. and Stoilov A. (2005). New approach for Finite Difference Method for Thermal Analysis of Passive Solar Systems. Department of Computer systems, South -West University, Bulgaria. 
20. S. W. Churchill and H. H. S. Chu, "Correlating equations for laminar and turbulent free convection from a vertical plate," International Journal of Heat and Mass Transfer, vol. 18, no. 11, pp. 1323-1329, 1975.

21. Ruiz A., Salmeron J. M., Sanchez F., Gonzalez R. and Alvarez S. (2005). Calculation model for Trombe walls and its use as a passive cooling technique. Passive and Low Energy Cooling for the Built Environment, Spain.

22. Mahmood, I., Jameel, W. W., \& Khaleel, L. A. (2013). Improved oxidation resistance for thermal barrier ceramic coating project. Int. J. Res. Eng. \& Technol, 1(1).

23. Turkan Goksal Ozbalta and Semiha Kartal, (2010). Heat gain through Trombe wall using solar energy in a cold region of Turkey. Scientific Research and Essays vol. 5 18, pp. 2768-2778, Turkey.

24. Zalewski L., Lassue S., Duthoit B., Butez M. (2002). Study of Solar walls \& validating a Simulation model. Building and Environment, 37 109-121, France.

25. Zondag HA, De Vries DW, Van Helden WGJ, Van Zolingen RJC, Van Steenhoven AA. The thermal and electrical yield of a PV-thermal collector. Solar Energy 2002;72(2):113-28. 